\title{
Higher Education Institutions as
}

\section{Strategic Actors}

\author{
JEAN-CLAUDETHOENIG* and CATHERINE \\ PARADEISE** \\ *UMR 7088 CNRS - DRM, Université Paris-Dauphine, Place du Maréchal de \\ Lattre de Tassigny, F - 75775 Paris Cedex, France. \\ Email: jeanclaude.thoenig@free.fr \\ **LISIS, Université Paris-Est Marne-la-Vallée, 5, boulevard Descartes, \\ Champs-sur-Marne, F-77454 Marne-La-Vallée Cedex 02, France. \\ Email: Catherine.Paradeise@u-pem.fr
}

\begin{abstract}
How to assess and enhance the strategic capacity of universities? This article suggests a managerial perspective derived from evidence-based social science knowledge. It lists major facets any local strategizing should address. It underlines the key role endogenous organizational capabilities play to make it happen or not in a sustainable manner. Three sets of social properties are evidenced: the way academic human resources are actually managed, the cultural norms appropriated by its members about their affiliation to their institution as a community, and the organizational governance at work between the various parts of the institution. Reminding us that the capacity to strategize is an outcome of actual organizational fabrication processes, the article also lists a series of booby-traps to avoid.
\end{abstract}

Obvious reasons explain why strategy is nowadays a relevant concern when not a decisive issue. Higher education institutions are requested to define and position a vision of their own future because their business has become more competitive than ever. They operate in an unstable when not disrupted environment. The certainty and predictability that for many years characterized the training of the elites and the production of knowledge have vanished. Since the final years of the twentieth century, profound changes have occurred: a wave of baby boomer student massification, commodification of higher education, globalization of academic supply, world standardization of quality criteria, less taxpayer money allocated to university budgets, not to mention the introduction of steering tools such as those associated with the New Public Management doxa. ${ }^{1}$

Within very few years, strategizing has given birth to an impressive number of publications by consultants providing off-the-shelf advice and by practitioners 
describing why they have been successful when in charge of heading universities. Such approaches are, to a large extent, fairy tales.

Although the aim of this paper is not to comprehensively review the state of the art in the matter, it is nevertheless worth mentioning a few recurrent cognitive and instrumental patterns taken for granted by many authors in the field, and by their supporters. At least some of these were already discussed, if not criticized, by social scientists many years ago when the topic of strategy or business policy became a priority for for-profit institutions, such as firms operating in competitive markets. This is because designing and implementing successful strategies is an art that is far from common sense.

First, academic strategizing is approached as a set of administrative recipes and procedural techniques that are a-contextual. What is peddled are one-size-fits-all prescriptions. What may have worked or failed here is postulated to work, or fail, anywhere else. Such recipes and techniques become proverbs of administration, assuming the existence of one best way to design the content of successful policies. ${ }^{2}$ What is required from one university, it is claimed, is to imitate some model developed elsewhere. For instance, universities located in Continental Europe should simply copy how leading US universities maximize academic creativity. The paradox is that such an administrative approach opens the door to increasing bureaucratic rigidities and generates lower capacities to adapt to evolving and differentiated environments. ${ }^{3}$

Second, academic strategizing is considered as being basically the production of some formal policy statement. For instance, a university that displays on its website a declaration formally endorsed by its heads is assumed to behave as a strategic actor. One that does not is supposed to be lagging. In the extreme case, the absence of a formalized programme is often perceived as if the institution does not have any policy or vision. In real life, albeit tacitly or implicitly, there may indeed not be any shared visions shaping common preferences and relevant lines of conduct. The university may be perceived as acting as an erratic institution, as a kind of garbage-can organization when making choices or modelling its future. ${ }^{4}$ According to this approach, the person to blame if no strategy is designed or if it fails to achieve its targets is the head of the institution. Change the president or the chancellor. On top of being a managing director with charisma or a person of providence, the skills needed to be an effective planner could be acquired by attending some courses - for instance in a management school - about policy design and environmental scanning.

Third, by emphasizing the role and skills of those who are formally in command of the institution, strategic management consultants and theorists may underestimate or even ignore how relevant middle and even lower levels of the institution's formal chain of authority may be. While the latter are supposed to participate at some point in the procedure of strategy building, at the end of the day the job is in the hands of the top levels - presidents, rectors, provosts, boards - meaning those who control the formal decision-making phase. These levels act and should act as principals who run their institution in line with the guidelines of agency theory. Here again, pioneering 
contributions made by organizational theorists have underlined how much more complex this is in actual cases. ${ }^{5}$ What occurs in firms also occurs in universities, whether public or private, which are craft-based, relying on highly trained professionals demanding control of their own work. ${ }^{6}$ As organizations they are loosely coupled collective action systems submitted to centrifugal dynamics. ${ }^{7}$ Given the fact that the social integration processes in use are very differentiated across universities, prescriptions about strategizing are prone to underestimate the importance of the implementation phase. Actual policies have to be considered as the sum of the acts and non-acts generated at all levels of the university and that shape, even in an unobtrusive manner, the way the institution positions itself in its environment. Building continuity between the various parts of the institution, the top and the bottom, and across the numerous departments and disciplines all year long is quite a challenge, as organizational sociologists keep observing and analysing. ${ }^{8}$

\section{Strategic Capacity 9}

Although higher education as a business evidences a remarkable degree of differentiation between the institutions operating in the sector, macroevolutions such as those mentioned above may a priori suggest that an irreversible trend is under way which, at the meso-level, erases specificities such as differences linked to national steering models, to institutions operating under different legal statuses, or to the formal missions assigned to such and such category of universities.

Yet this is far from being the case. Specificities remain important when studying in depth how universities operate. This is the case with how they position themselves to produce academic quality. Strategically speaking, several routes to achieve distinction are still travelled, even by institutions that operate in the same formal category of missions and that are located in the same country.

The term 'strategic capacity' is preferable to the term 'strategy' for at least two reasons.

While common-sense considers that what matters above all is the design of the strategy content, the way to define this content being considered as an ancillary or second-order problem: however, a local order perspective highlights that this is far from being true.

In real life, strategies are run continuously. They are co-creative endeavours. They result from a discontinuous accumulation of disjointed initiatives and rationales for action. They emerge as outcomes of initiatives produced by many actors across the institution. They are contextual, contingent and implicit. They mobilize cognitive dimensions about how the environment is perceived and interpreted today and in the years to come. Therefore, opportunities and constraints for action-taking involve access and dependence on outside actors, starting with the attention given to them as providing resources or as potential competitors.

A strategic capacity may be defined as a Gestalt that combines four major components. The first component refers to the time horizon that is taken for granted in which to structure policy-making and which provides a shared reference for action 
taking. Does, the institution as a collective actor project itself into the future, and if so, around which term? And how does it do so?

The second component relates to the action environments that are considered as the most relevant for the institution, in terms of opportunity providers as well as in terms of constraint sources for success. What kind of environments are perceived as relevant, which outside sectors and actors are supposed to matter today and tomorrow, which evolutions, if any, are considered as worth paying special attention to? Are they considered as turbulent, and therefore as a source of risk, or are they perceived as predictable? Are opportunities and threats identified and taken into account, or do they remain in a zone of indifference?

The third facet covers the resources to implement the strategic ambition. Are the ambitions or hopes in line with the time horizon, attention and means that the institution is able and willing to mobilize for that purpose? How will the various internal parts react, interpret and appropriate the initiatives at their own level? Is there some slack available in terms of resources and management capacity? Are some changes needed in the way the institution operates - division of labour, expertise, budgeting, etc. - and are they anticipated? How to protect some tangible and intangible institutional assets?

The fourth facet relates to the actual involvement and credibility lent to the strategic facet. Do the members of the institution consider the desires and ambitions of the institution as just one more piece of paper, a matter of discourse and concern only for those who voice them, or do they too feel accountable for the future? Do they feel on board or do they act as free riders? Do faculty and administrative staff members consider strategizing as a moral duty? At the end of the day, who owns the strategic vision and formulates the requirements?

To assess how weak or robust an institutional strategic capacity is, Table 1 suggests an analytical grid, listing a series of observations practitioners and policy-makers may refer to when not putting them together themselves by wandering around the institution.

Higher education institutions differ according to their capacity to strategize.

At one extreme of the spectrum some show a very weak capacity, if not a total lack of capacity, to build up and manage a collective asset, enabling them to act as strategic actors in a sustainable and distinctive manner. Their main time objective set is not even short term: tomorrow will be as today is. They operate without considering potential change processes in their environment as if the future would remain predictable in terms of societal needs, academic developments, and steering expectations. If things turn sour for them they will blame external scapegoats such as globalization or politics. They do not try to anticipate, and react passively to outside events. No common action theory is shared internally. Strategizing is considered one more technocratic procedure, or a piece of paper with which to comply, and which the general management should handle itself. This often coincides with the latter enjoying no actual internal moral support, and trying to avoid any perspective that would give the impression that one or other unit or mission - for instance research or IT - is being favoured over other, equally deserving, units or missions. 
Table 1. Assessing strategic capacity components.

\begin{tabular}{|c|c|c|}
\hline & Weak capacity & Robust capacity \\
\hline $\begin{array}{l}\text { 1. Attention paid to the impact of competitive } \\
\text { dynamics }\end{array}$ & Low & High \\
\hline $\begin{array}{l}\text { 2. Attention paid to national and international } \\
\text { contexts }\end{array}$ & Low & High \\
\hline $\begin{array}{l}\text { 3. Attention paid to societal contexts and } \\
\text { evolution trends }\end{array}$ & Low & High \\
\hline 4. Main time objective set for strategizing & Short term & Mid- to long-term \\
\hline 5. Importance given to this time objective & Low & High \\
\hline $\begin{array}{l}\text { 6. Attention paid to resources for implementing } \\
\text { the strategy }\end{array}$ & Low & High \\
\hline 7. Attention paid to operational applications & Low & High \\
\hline $\begin{array}{l}\text { 8. How much does general management count in } \\
\text { strategizing }\end{array}$ & Little & A lot \\
\hline 9. How much academic staff really counts & Little & A lot \\
\hline 10. What strategizing expresses & $\begin{array}{l}\text { Speech by the } \\
\text { management }\end{array}$ & $\begin{array}{l}\text { Policy endorsed } \\
\text { by all members }\end{array}$ \\
\hline 11. Importance given to the status of strategizing & Secondary & Priority \\
\hline
\end{tabular}

At the other extreme, an academic institution benefiting from a robust strategic capacity shows a sophisticated and flexible understanding of coming developments and of its relevant business context. Its members and units share a good understanding of how and why each may contribute to building and maintaining a distinctive quality image. In other terms, a common policy or action theory links acts to outcomes. If we do A, then the chances are great that B will follow. It becomes a successful action theory. The institution pays great care to getting the timing right for operating strategically in the coming years. Any outside event that may be considered as a relevant signal in terms of opportunities or risks is carefully monitored. Strategizing is of concern to all levels and across all units of the institution, each elaborating its own scanning and action programme for the future while at the same time keeping in mind the latter's compatibility with the vision and action project as defined for the whole institution.

It is difficult to give a reliable estimate of universities as sorted according to strategic capacity. Yet four observations may be worth mentioning.

First, major differences are visible between institutions that operate within the same country - for instance France, the USA, the UK, Germany, etc. - or are structured according to an identical formal tradition, for instance Napoleonic, Humboldtian or Anglo-Saxon. But major similarities may occur, for instance, between research universities that do not operate under the same legal status: whether private or public, their policies or strategies are quite similar in most respects creativity, education, research, fund raising, etc. - and they show a similar level of strategic capacity - in terms of flexibility, opportunity scanning, etc. ${ }^{10}$ 
Second, between very weak capacity institutions and very robust ones, one intermediary profile mixing components from both extremes is worth considering. It evidences a rather robust capacity. Commitment in terms of strategizing is intensive, and high on its agenda, and gets priority from the general management of the institution. While the very top really is engaged in this, the academic staff at large are less so, or not at all. Strategic capacity is short to mid-term driven, its aim being to upgrade the status of the institution as defined by academic rankings as soon as possible. The relevant action environment is perceived as an arena for competitive zero-sum games between academic institutions. A lot of attention is given to operational resources that help attract faculty with high visibility. These may be academics whose publication record is judged as outstanding in their discipline but whose contribution to institutional projects or ambitions in education or in interdisciplinary projects may remain questionable. Such a strategizing capacity is often described as characteristic of the wannabe approach. ${ }^{11}$ It differs dramatically from the very robust model because it is obsessed by only one rationale - competing for a better institutional ranking - and gives full hegemony to the head of the university - strategizing being a top-down model.

Third, observation suggests that strategic capacity is distributed in an asymmetric manner inside the academic business. Institutions evidencing a robust capacity are not as numerous as those that are weak in strategizing. While precise figures are lacking for the 15,000 or more universities active around the globe in 2014 , one is forcibly struck by one recurrent fact: the high number of institutions that operate without a capacity to position themselves in a distinctive manner because they lack endogenous capacity to express it. For sure, in some countries, national steering policies that do not allocate relevant degrees of formal autonomy to local institutions do not help. Nevertheless, this is also the case in countries that, a few years ago, started to decentralize policy-making - the excuse being that quite a few years are needed to assimilate change, in particular when New Public Management tools had regulated centre-local relationships according to agency theory principles. Weak capacity is also found among many institutions set up to handle the student massification that occurred when the baby-boomer rush started in the late 1960s. More than ever they are today challenged about their identity and future business model. Last but not least, some universities with a long historical record and that have been considered as flagships nationally and internationally also show a strikingly weak strategic capacity profile. They have failed to adapt to the revolution that has transformed the academic business since the last third of the twentieth century. These venerable institutions continue to rely on their past assets and ways of doing things. Why should they for instance stop trusting their senior professors or mandarins? They act as if strategizing is unnecessary for them, and only something for ambitious newcomers and a few arrogant star institutions.

A fourth and final comment underlines a possible association between the level of strategic capacity and the academic quality positioning of a university.

Although exceptions may be quite numerous, capacities vary according to the way quality production is positioned and vice versa. A comparative field study of a series 
of 16 institutions in six different countries defines this positioning as a set of four quality regimes combining two parameters. The first is the degree of prestige, visibility in terms of social image or reputation. The second is the degree of excellence as measured by performances quantified by ranking scales. ${ }^{12}$ Both may be considered as reliable proxies of strategic positioning on the academic market.

Universities that are very weak in terms of prestige and very weak as assessed by excellence rankings, as well as universities - venerables - that are highly visible in terms of prestige but are lagging, if not outright weak, in terms of performance indicators, tend to show very weak to weak strategic capacities.

Universities that are highly visible in terms of prestige and that also steadily rank at the very top on performance ranking scales nationally and internationally, tend to show strong to very strong strategic capacity. They belong to a rather small group that includes the elite of the rankings. This does not refer to the usual worldwide elitist leaders mentioned as references, such as Harvard or Oxford. Some robust capacity may also be shown at a more regional or even local level by institutions whose international status is more modest but which in their environment occupy a leadership position or act as references for specific missions, such as professional training, research excellence in a very few niches, or local development.

Wannabes tend to show a rather strong but more fragile and temporary capacity. Their profile underlines a broader property of strategic capacity. In their case, upgrading this capacity is used as leverage to increase their image in a pro-active manner by improving their scoreboard as measured by performance rankings nationally or internationally. In the case of top-of-the-pile institutions, a weakening of their strategic capacity may jeopardize their status as references in terms of prestige and excellence. Therefore, the question to address for managerial purposes is to understand what are the endogenous factors required to generate a robust capacity.

\section{Organizational Capabilities Generating Strategic Capacity}

What makes a strategic capacity weak or robust? What assets or resources should be combined to enhance its level? What factors become liabilities in which conditions?

Research suggests that successful strategic players in the business of academia are institutions that exhibit and master specific organizational capabilities. To build a successful action project, and to embed it in a distinctive niche in spite of all the turbulence occurring in this market, requires - more than ever - internal assets of a special kind, namely organizational or social ones.

To fabricate actual strategic positioning is basically a co-production of a set of local social processes. Money, land, infrastructures for research and education, sport facilities and libraries, and even having talented academics on the payroll, may help. Yet such resources are far from sufficient. Acting strategically in a sustainable manner requires something else, less obtrusive, less visible, difficult to achieve in the short term and by a mere top-down act of will: a collective capability to line up the internal components of the university so that they achieve some common goals, and generate some sustainable compatibility or fit between internal differentiation and integration 
across the institution's internal subunits. University management deals with people business: its challenge is to reconcile the multiple identities of faculty as members of the same institution and as members of scientific professions or communities at large so as to mobilize them around a set of cohesive aims or ambitions.

Three sets of social processes play a key role in providing and shaping strategic capacity. Some hinder the emergence of a strategic capacity. Others facilitate and reinforce it. Three kinds of organizational capabilities can be assessed in detail by qualifying a few characteristics for each one. They shall be detailed by comparing the strategic capacity profiles listed above, namely those with a weak capacity and those with a robust one, and in between the two special cases of the venerable and the wannabe profile.

As listed in Table 2, a first set of such processes relates to the ways and arrangements regulating how academic human resources are and should be handled. Two aspects play a key role: the mission individual faculty members understand and define as their work or task priority, and the way single faculty member performance is assessed, whether for recruitment, promotion or procedural purposes.

Table 3 refers to a second set of organizational capabilities, namely cultural norms and expectations that rule what is considered as appropriate for a single person in terms of institutional belonging or loyalty. It refers to how faculty and staff are socialized by their institution and which social status or image is linked to the fact of being a member of such and such university. Indeed, universities as academic communities may be more or less cohesive and able to socially control their members along similar patterns.

Table 4 underlines a third set of organizational processes that synthesize the actual governance style and processes at work across the institution. It relates to the social processes enacted to achieve a dense compatibility between integration and differentiation requirements among its various parts, disciplines and hierarchical authority levels that is able to deal with tough challenges. These processes provide frameworks for the actions of the numerous units and disciplines, in addition to the mere coordinating role played by formal authority. Tacit cooperation and implicit adjustment criteria matter given the diversity of environments and outside stakeholders the institution is dependent upon. Organizational flexibility required in the short term is, in different ways, even tighter than that of many companies, covering ambitions with regard to recruitment and selection of good students as well as competing for research money and donations or pioneering new education programmes. ${ }^{13}$ Feeling accountable for safeguarding the general interest of the institution requires some form of altruism as well as some common ways to interpret and scan the environment. On top of this, scientific leadership and institutional success cannot be asserted at the same extremely fast rate as market domination can be achieved in certain highly innovative business sectors such as digital applications.

\section{Organizational Development Matters}

As with any firm, universities should be equipped with a robust strategic capacity, for massive and unpredictable developments occur in their business too. Nevertheless, 
Table 2. Human resource management of faculty members.

\begin{tabular}{|c|c|c|c|c|}
\hline Relevant components & $\begin{array}{l}\text { Weak strategic capacity } \\
\text { institutions }\end{array}$ & $\begin{array}{l}\text { Robust strategic capacity } \\
\text { institutions }\end{array}$ & Venerables & Wannabes \\
\hline $\begin{array}{l}\text { 1. Relative importance lent to } \\
\text { research mission }\end{array}$ & $\begin{array}{l}\text { Little at the institutional } \\
\text { level. } \\
\text { Variable at the level of a } \\
\text { single department }\end{array}$ & Great at all levels & Moderate to great & Great \\
\hline $\begin{array}{l}\text { 2. Relative importance lent to } \\
\text { teaching mission }\end{array}$ & $\begin{array}{l}\text { Moderate at the } \\
\text { institutional level. } \\
\text { Variable at the level of a } \\
\text { single department }\end{array}$ & Great at all levels & Moderate & Moderate \\
\hline 3. What mission matters most & Teaching & Research & Research & Research \\
\hline $\begin{array}{l}\text { 4. Attention paid to assessing these } \\
\text { activities }\end{array}$ & $\begin{array}{l}\text { Low at the institutional } \\
\text { level. } \\
\text { Variable at the level of a } \\
\text { single department }\end{array}$ & High & Moderate & High \\
\hline $\begin{array}{l}\text { 5. What counts the most in } \\
\text { defining assessment standards }\end{array}$ & $\begin{array}{l}\text { Colleagues from the same } \\
\text { department and } \\
\text { discipline }\end{array}$ & $\begin{array}{l}\text { The academic community }+ \text { the } \\
\text { professional invisible outside } \\
\text { college }\end{array}$ & $\begin{array}{l}\text { Senior professors of } \\
\text { the institution }\end{array}$ & $\begin{array}{l}\text { General management based } \\
\text { on professional standards }\end{array}$ \\
\hline $\begin{array}{l}\text { 6. Standards making the difference } \\
\text { in assessing academic } \\
\text { performance }\end{array}$ & According to departments & $\begin{array}{l}\text { Talent and promises anticipated of } \\
\text { single faculty members }\end{array}$ & $\begin{array}{l}\text { According to } \\
\text { departments and } \\
\text { chair holders }\end{array}$ & $\begin{array}{l}\text { Publication numbers in } \\
\text { recent years in top-rated } \\
\text { journals }\end{array}$ \\
\hline
\end{tabular}


Table 3. Salience of academic staff cultural characteristics.

\begin{tabular}{|c|c|c|c|c|}
\hline Relevant components & $\begin{array}{l}\text { Weak strategic } \\
\text { capacity }\end{array}$ & $\begin{array}{l}\text { Robust } \\
\text { strategic } \\
\text { capacity }\end{array}$ & Venerables & Wannabes \\
\hline $\begin{array}{l}\text { 1. Social status associated } \\
\text { with being a member } \\
\text { of the university }\end{array}$ & $\begin{array}{l}\text { Moderately } \\
\text { high }\end{array}$ & $\begin{array}{l}\text { Moderately } \\
\text { high }\end{array}$ & High & High \\
\hline $\begin{array}{l}\text { 2. Image attached to the } \\
\text { social status of } \\
\text { member of the } \\
\text { institution }\end{array}$ & Teacher & Teacher & Academic & Knowledge worker \\
\hline $\begin{array}{l}\text { 3. Strength of local } \\
\text { standards and values }\end{array}$ & Weak & Strong & Strong & Weak \\
\hline $\begin{array}{l}\text { 4. Socialization process } \\
\text { of faculty members }\end{array}$ & $\begin{array}{l}\text { In situ and } \\
\text { through } \\
\text { personal } \\
\text { learning }\end{array}$ & $\begin{array}{l}\text { In situ and } \\
\text { through } \\
\text { personal } \\
\text { learning }\end{array}$ & $\begin{array}{l}\text { In situ by } \\
\text { statutory } \\
\text { peers }\end{array}$ & $\begin{array}{l}\text { Outside the } \\
\text { institution by } \\
\text { disciplinary } \\
\text { communities }\end{array}$ \\
\hline $\begin{array}{l}\text { 5. Loyalty to the } \\
\text { institution }\end{array}$ & Moderate & Strong & Strong & Weak \\
\hline
\end{tabular}

what seems so obvious at first sight is not easy at all to achieve. The main reason relates to the fact that to act strategically requires internal capabilities such as those identified by Tables 2 to 4 . Such social, cognitive, cultural and relational norms and processes are key to set up an internal ecology that allows an institution to act according to an action theory enabling it to scan outside societal dynamics, and to decipher opportunities and risks of various sorts in real time.

This organizational ecology allows strategy to operate as a quasi-experimental process given the fact that the institution as a whole can no longer afford to make losing bets, ignore changing expectations from outside stakeholders, or misunderstand how to take the latter into account. Strategies in changing environments should frame action launching and then see the outcomes or actual first results produced, understand whether the aims or ambitions they were supposed to serve made sense, and if necessary, revise the theory of action in use.

Learning in real time implies that two pre-requirements be satisfied. One relates to interpretation and subjectivity skills active at all levels across the entire academic institution. The other relates to the capacity to integrate them into a common framework without keeping them differentiated too much, as suggested by Table 4 . Table 2 highlights the latent function played by the way academic human resources are actually managed. When internal evaluation is taken seriously, and not just as scientific publications bean counting, it produces side effects of cognitive learning across disciplines. Institutions applying a criterion such as academic talent are also more aware of emergent scientific agendas and knowledge frontiers.

To successfully enhance organizational capabilities, academic leadership inside a university requires close attention to their development, an adequate set of skills, and 
Table 4. Organizational governance of the institution.

\begin{tabular}{|c|c|c|c|c|}
\hline Relevant components & $\begin{array}{l}\text { Weak strategic } \\
\text { capacity institutions }\end{array}$ & $\begin{array}{l}\text { Robust strategic } \\
\text { capacity institutions }\end{array}$ & Venerables & Wannabes \\
\hline 1. Relations between academics & $\begin{array}{l}\text { Peers bound together } \\
\text { by equality criteria }\end{array}$ & $\begin{array}{l}\text { Members of the same } \\
\text { community }\end{array}$ & $\begin{array}{l}\text { Colleagues who are members } \\
\text { of the same meritocracy }\end{array}$ & $\begin{array}{l}\text { Individuals competing inside the } \\
\text { institution and on academic markets }\end{array}$ \\
\hline $\begin{array}{l}\text { 2. Valuation of management roles } \\
\text { fulfilled by faculty members }\end{array}$ & Little or not at all & Valued & Little or not at all & Valued \\
\hline $\begin{array}{l}\text { 3. Power sharing between } \\
\text { management and academics }\end{array}$ & $\begin{array}{l}\text { Weak management } \\
\text { Quite weak academics }\end{array}$ & $\begin{array}{l}\text { Strong management } \\
\text { Strong teaching staff }\end{array}$ & $\begin{array}{l}\text { Weak management } \\
\text { Strong teaching staff }\end{array}$ & $\begin{array}{l}\text { Strong management } \\
\text { Weak teaching staff }\end{array}$ \\
\hline $\begin{array}{l}\text { 4. How the institution works as an } \\
\text { organization }\end{array}$ & $\begin{array}{l}\text { Centrifugal. } \\
\text { Weak integration } \\
\text { amongst its } \\
\text { components }\end{array}$ & $\begin{array}{l}\text { Neither centrifugal } \\
\text { not centripetal. } \\
\text { Strong integration } \\
\text { among its } \\
\text { components }\end{array}$ & $\begin{array}{l}\text { Centrifugal. } \\
\text { Weak integration amongst } \\
\text { its components }\end{array}$ & $\begin{array}{l}\text { Centripetal. } \\
\text { Strong integration amongst its } \\
\text { components }\end{array}$ \\
\hline
\end{tabular}


a relevant amount of time. General management as well as academics in charge of departments and research laboratories should behave as facilitators of formal but also informal conversation arenas, and as coaches of the faculty as well as of persons in charge of the administrative staff. The social fabric should be one of their main concerns. To develop such capabilities, time is required. Ten to 15 years is not an uncommon horizon. While robust strategic capacities may be destroyed in a very few years, enhancing weak ones cannot be achieved by decree.

To achieve a tight coupling between strategic capacity and organizational capabilities also raises the issue of how policymakers and steering bodies of academic systems may or may not help this to occur at the level of single institutions. First, they should consider that relevant strategic capacity at the field level requires relevant autonomy, for instance in terms of margins of discretion in fields such as human resources, revenues and expenses, recruitment fees, diplomas, etc. Unfortunately, while the principle is widely shared, in real life it is not fully implemented in several countries and states. ${ }^{14}$ Second, national policies, either explicitly or tacitly, may refer to a benchmark that should be common for any university, for instance the research university or the so-called worldclass university model. Many of the instrumental prescriptions and performance indicators they prescribe may not really make sense as success models in view of the complete range of higher education missions universities may fulfil.

\section{References}

1. C. Paradeise and J.C. Thoenig (2015) In Search of Academic Quality (London: Macmillan).

2. H.A. Simon (1946) The proverbs of administration. Public Administration Review, 6(1), pp. 53-67.

3. M. Crozier (1963) The Bureaucratic Phenomenon (Chicago: The University of Chicago Press).

4. M.D. Cohen, J. G. March and J. P. Olsen (1972) A garbage can model of organizational choice. Administrative Science Quarterly, pp. 1-25.

5. R.M. Cyert and J.G. March (1963) A Behavioral Theory of the Firm (Englewood Cliffs, NJ: Prentice Hall). See also J.L. Bower (1970) Managing the resource allocation process: A study of corporate planning and investment (Cambridge, MA: Harvard Business School Press).

6. J.Q. Wilson (1986) Bureaucracy: What Government Agencies Do and Why They Do It (New York: Basic Books).

7. B.R. Clark (1995) Complexity and differentiation: the deepening problem of university integration. In D.D. Dill and B. Sporn, (Eds) Emerging Patterns of Social Demand and University Reform (Oxford: IAU Press/Pergamon Press), pp. 159-170.

8. J.C. Thoenig and C. Paradeise (2016) Strategic capacity and organizational capabilities. A challenge for universities. Minerva, 54(3), pp. 293-324.

9. D.J. Teece, G. Pisano and A. Shuen (1997) Dynamic capabilities and strategic management. Strategic Management Journal, 18, pp. 509-533.

10. C. Paradeise and J.C. Thoenig (2014) Organizational governance and the production of academic quality: Lessons from two top U.S. research universities. Minerva, 52(4), pp. 381-417.

11. G. Tuchman (2009) Wannabe U: Inside the Corporate University (Chicago: The University of Chicago Press). 
12. R.K. Merton (1973) The Sociology of Science: Theoretical and Empirical Investigations (Chicago: The University of Chicago Press).

13. J.R. Navarro and F.O. Gallardo (2003) A model of strategic changes: Universities and dynamic capabilities. Higher Education Policy, 16, 199-212.

14. T. Estermann, T. Nokkala and M. Steinel (2011) University Autonomy in Europe II: The Scoreboard (Brussels: The European University Association).

\begin{abstract}
About the Authors
Jean-Claude Thoenig is research director emeritus at the Centre National de la Recherche Scientifique. As a sociologist, he has studied public management, policy analysis and the sociology of organization-related topics. His latest publication is 'Developing top academic institutions to support innovation' in S. Schepers and K. Gretschmann (Eds) (2016) Revolutionising EU Innovation Policy: Pioneering the Future (London: Palgrave).

Catherine Paradeise is emeritus University Professor at Université Paris-Est Marne-la-Vallée. As a sociologist, she has studied labour relationships, labour markets, higher education and research. Her latest publication, co-edited with E. Popp Berman, is The University under Pressure. Research in the Sociology of Organizations, vol. 46 (Bingley: Emerald Group Publishing, 2016).
\end{abstract}

